\title{
Ophidiiform fishes from the Oligocene-early Miocene of Moravia, Czech Republic
}

\author{
Tomáš PřlKRYl \& Giorgio Carnevale
}

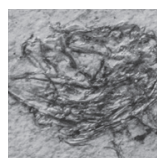

\begin{abstract}
Oligocene (Rupelian) and Oligocene-lower Miocene (Egerian) fossiliferous deposits from Moravia (Czech Republic) provided several specimens of ophidiiform fishes that are described herein and assigned to three species-level taxa. The Rupelian taxa are known from three specimens each coming from a different locality (Nikolčice, Loučka, Mouchnice), and are recognized herein referred to as two separate species; one of these is of unknown position within Ophidiiformes ("Brotula" longipinnata), and the other is assigned to the family Bythitidae (Propteridium profondae). The only available specimen collected from Egerian sediments of the Krumvír locality is assigned to a new brosmophycine bythitid genus and species, Kalabisia krumvirensis gen. \& sp. nov. The Oligocene to early Miocene record of Ophidiiformes of the Paratethyan realm is also provided. - Key words: Teleostei, Ophidiiformes, Bythitidae, Brosmophycinae, Paratethys, Oligocene, early Miocene.
\end{abstract}

Přikryl, T. \& Carnevale, G. 2018. Ophidiiform fishes from the Oligocene-early Miocene of Moravia, Czech Republic. Bulletin of Geosciences 93(4), 477-489 (12 figures, 3 tables). Czech Geological Survey, Prague. ISSN 1214-1119. Manuscript received August 12, 2018; accepted in revised form October 10, 2018; published online November 8, 2018; issued December 20, 2018.

Tomáš Přikryl, Institute of Geology of the Czech Academy of Sciences, Rozvojová 269, CZ-165 00 Prague 6, Czech Republic; prikryl@gli.cas.cz • Giorgio Carnevale, Dipartimento di Scienze della Terra, Università degli Studi di Torino, Via Valperga Caluso, 35, I-10125 Torino, Italia

Fishes of the order Ophidiiformes are widely distributed and inhabit a variety of environments, from abyssal trenches to shallow marine biotopes, including coral reefs. Several ophidiiforms enter brackish and freshwaters, and a few species are inquilines (e.g. Markle \& Olney 1990, Nielsen et al. 1999, Nelson et al. 2016). Despite this remarkable ability to adapt to various environments, the group seems to be rather conservative from a morphological point of view, showing an elongate body with dorsal and anal fins usually continuous and convergent with the caudal fin and thoracic or jugular pelvic fins (if present at all). The group is currently regarded as occupying a basal position within the Percomorphacea (Chen et al. 2014). Although some authors have pointed out that the absence of synapomorphies for the order does not allow the recognition of its monophyletic status (e.g. Rosen 1985), Carnevale \& Johnson (2015) reported the exclusion of the supraoccipital from the posterior margin of the neurocranium as a putative synapomorphy of ophidiiforms (see also Howes 1992). Its higher classification is usually considered as relatively stable, with two suborders containing two families each (for details regarding classification see, e.g. Nielsen et al. 1999, Nelson et al. 2016).

The fossil record of the Ophidiiformes is well documented by isolated otoliths that indicates a considerable diversity during the Paleogene (e.g. Nolf 1980, Schwarzhans 1981), with the present diversity consisting of 119 genera and about 531 species (see Nelson et al. 2016) regarded as a residue of the original splendor of the order (Nolf 2013). The skeletal record of the order is remarkably less rich than that of its otoliths. The oldest skeletal record dates back to the Upper Cretaceous (Carnevale \& Johnson 2015), with the species Pastorius methenyi, showing that the modern body plan of the group was already in existence at that time.

The oldest Cenozoic records based on articulated skeletal remains date back to the Paleocene-Eocene boundary (Eolamprogrammus senectus from Turkmenistan; Daniltshenko 1968) and to the early Eocene ("Ophidium" voltianum from Italy; Ampheristus tolipiacus from England; Carnevale et al. 2014, Schwarzhans et al. 2018). However, a more complete overview of the skeletal record of this group has recently been given by Carnevale \& Johnson (2015).

Herein, we focus on the skeletal record of ophidiiform fishes from the Oligocene and early Miocene of the Paratethys. The first Oligocene articulated skeletal specimen of an ophidiiform fish was described by Kramberger (1880) as Brotula (?) longipinnata from Nikolčice, Moravia, Czech Republic. Coeval deposits exposed in other localities of the same area have provided additional specimens, some of which were tentatively referred to 


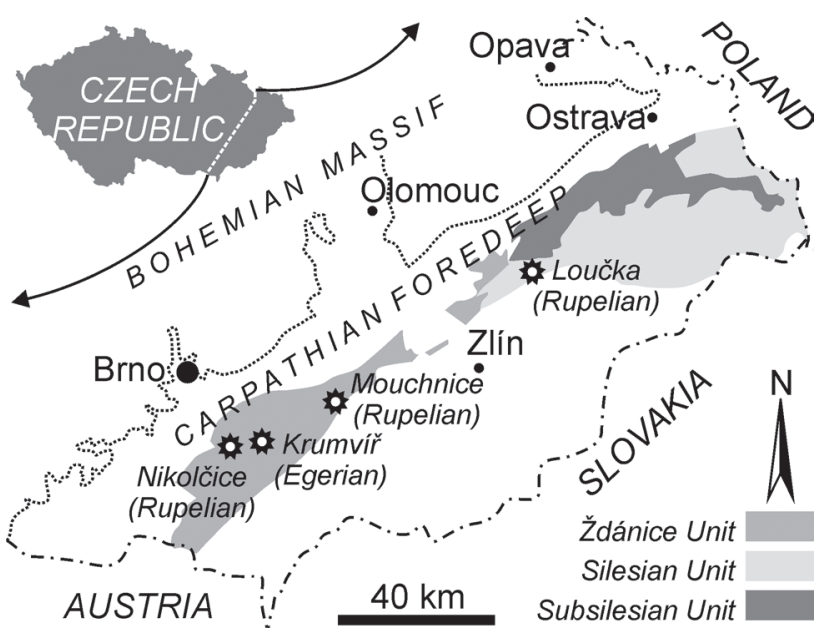

Figure 1. Geographic position of the localities that provided the fossils described herein. Distribution of the units follows Čtyřoký \& Stráník (1995).

an indeterminate species of the genus Propteridium by Gregorová (2013). Other fossil ophidiiforms have been reported from Romania and Ukraine (Paucă 1931, 1933), although these are largely incomplete and inadequately preserved. In the second part of the $20^{\text {th }}$ century, Daniltshenko (1960) described Protobrotula sobijevi from the Oligocene deposits of North Caucasus, and Ciobanu $(1970,1977)$ reported the species Propteridium profondae from Romania. Kotlarczyk et al. (2006) listed several ophidiiform taxa from the Polish Carpathians, although only Glyptophidium sp. has been described in detail (Świdnicki 1988). The Oligocene-early Miocene (Egerian) skeletal record of ophidiiform fishes from Moravia is limited to a few specimens, many of which are badly in need of revision.

Overall, the fossil record of ophidiiform fishes is very meager globally. Some Miocene records are known from Argentina (Riva Rossi et al. 2000), Japan (Sato 1962), Italy (Leonardi 1959), and Maryland (Carnevale \& Godfrey 2018).
The goal of this paper is therefore to describe the Oligo-Miocene ophidiiform fishes from Moravia and discuss their taxonomic placement. The Paratethyan record of the Ophidiiformes is also discussed.

\section{Material and methods}

The material described herein was collected from four Moravian localities (Fig. 1), including Nikolčice (Rupelian, Dynów Marlstone, Menilitic Fm., Ždánice Unit), Mouchnice (Rupelian, Dynów Marlstone, Menilitic Fm., Ždánice Unit), Loučka (Rupelian, Dynów Marlstone, Menilitic Fm., Silesian Unit; Přikryl et al. 2012, Přikryl \& Carnevale 2017), and Krumviŕr (Egerian, ŽdánickoHustopeče Fm., Ždánice Unit; Kalabis 1966, Brzobohatý et al. 1975). For information regarding the geological situation and stratigraphy see Gregorová (1997) and references therein.

Some of the specimens required mechanical preparation to expose parts of the skeletal structure; this was achieved using needles and small scalpels. The fossils were studied using a binocular stereomicroscope Leica MZ6 equipped with camera lucida drawing arm and a Canon EOS 1000D camera (at the Institute of Geology of the Czech Academy of Sciences), as well as using digital microscope Keyence (at the National Museum in Prague). Standard length (SL) is used throughout.

Anatomical abbreviations: A - anal fin; av - abdominal vertebra; br - branchiostegal rays; cl cleithrum; cv - caudal vertebra; D - dorsal fin; dcr - dorsicranium; den - dentary; dpa - dorsal prezygapophysis; ect - ectopterygoid; ep - epural; epi - epineural; eth lateral ethmoid; exo - exoccipital; fr - frontal; gr - gill rakers; hyp - hypural; $\mathrm{mx}$ - maxilla; ns - neural spine; op - opercle; P - pectoral fin; pap - parapophysis; pcl postcleithrum; php - parhypural; pmx - premaxilla; pop - preopercle; psph - parasphenoid; pu - preural

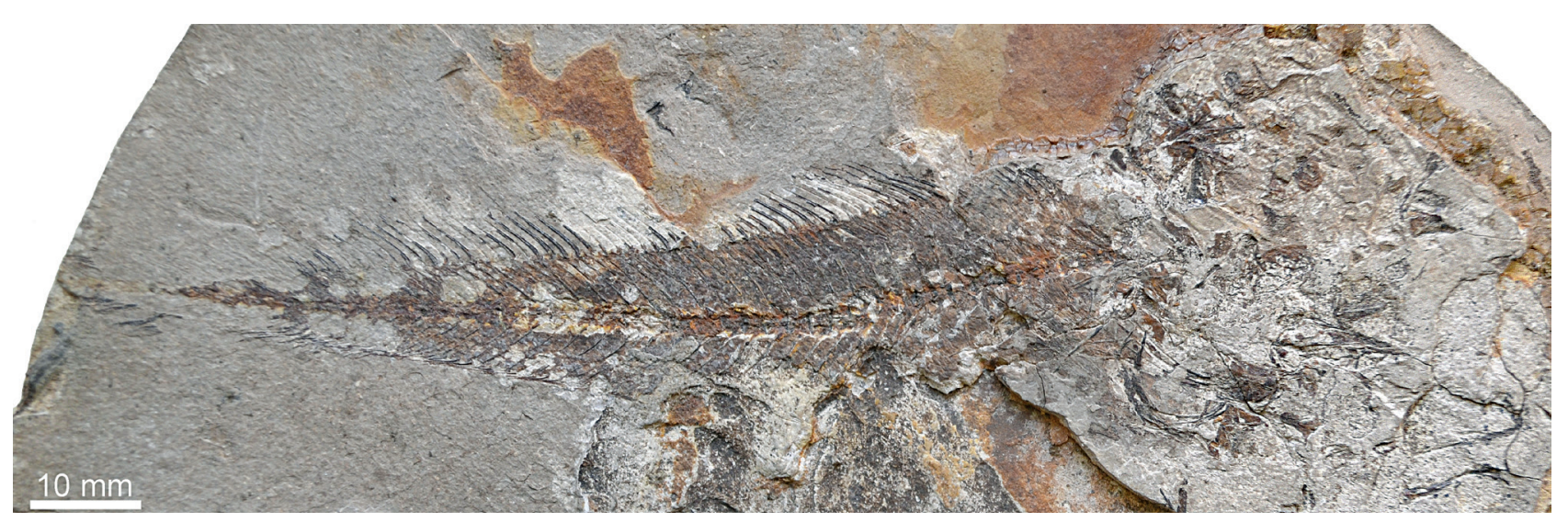

Figure 2. "Brotula” longipinnata Kramberger, 1880. Nikolčice, Rupelian. GB 2007/27/1, holotype, right lateral view. 
vertebra; q - quadrate; $r$ - rib; sn - supraneural; soc - supraoccipital; $\mathrm{u}$ - ural vertebra; $\mathrm{V}$ - pelvic fin; vom - vomer; vpa - ventral prezygapophysis.

Institutional abbreviations: GB - Geologische Bundesanstalt, Vienna, Austria; MSNPN - Natural Sciences Museum, Piatra Neamţ, Romania; MZM - Moravian Museum, Brno, Czech Republic; NMP - National Museum, Prague, Czech Republic; USNM - National Museum of Natural History, Smithsonian Institution, Washington, D.C., USA.

\section{Systematic palaeontology}

Division Percomorphacea Wiley \& Johnson, 2010

Order Ophidiiformes Berg, 1937

\section{"Brotula" longipinnata Kramberger, 1880}

Figures 2-4

1880 Brotula (?) longipinnata. - Kramberger, p. 570, pl. 8, fig. 6.

Material. - GB 2007/27/1, holotype, partially complete articulated skeleton, lacking most of the head and the posterior portion of the caudal region, Nikolčice (Figs 2, 3); NMP Pv 10053a + b, partially complete articulated skeleton lacking the head and part of the dorsal fin, in part and counterpart, Loučka (Fig. 4).

Description. - The holotypic specimen is incomplete, with a largely disarticulated and partially preserved head skeleton; the postcranial portion of the body is better preserved and has a gradually tapering outline. The specimen from the Loučka locality (NMP Pv 10053a, b) is also largely incomplete, lacking the head skeleton but having a gradually tapering body consistent with that of the holotype (Fig. 4).

Neurocranial remains are partially recognizable in the holotype, displaced from their original position and inadequately preserved. Part of a relatively short dorsicranium is recognizable, although the identification of the bony elements is not possible due to poor preservation. The vomer has no identifiable teeth. The premaxilla bears well developed and separate articular and ascending processes, separated from each other by an angle of about $20^{\circ}$. The dentary is firmly articulated to the anguloarticular, forming an almost complete nearly triangular lower jaw. There is no evidence of jaw teeth. Fragments of the preopercle and opercle can be recognized. The opercle

Figure 3. "Brotula" longipinnata Kramberger, 1880. Nikolčice, Rupelian. Interpretative reconstruction of the holotype GB 2007/27/1.

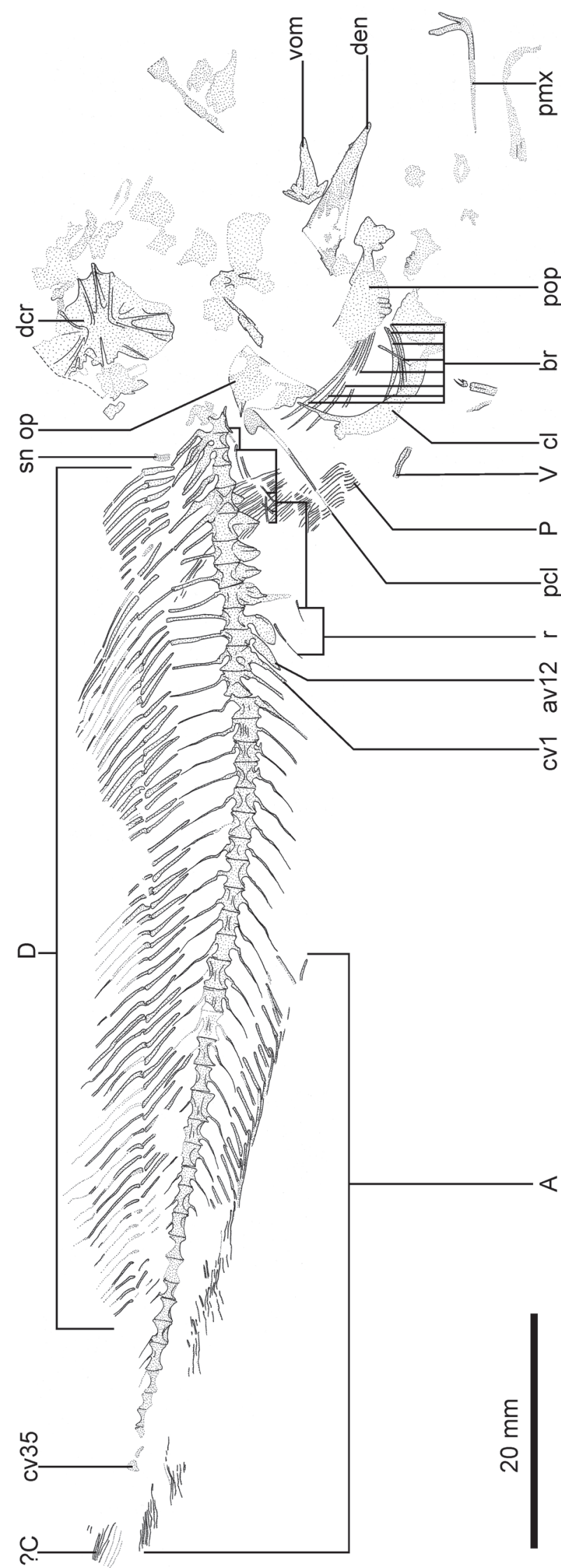


is approximately triangular, with a single horizontal spine projecting posteriorly. Eight elongate and saber-like branchiostegal rays are recognizable.

The vertebral column seems to consists of 52-53 (12 abdominal and about 40-41 caudal) vertebrae, including the urostylar complex. The first six abdominal vertebrae bear well-developed neural spines that are posterodorsally inclined, while those of the six posterior abdominal vertebrae are almost rod-like and nearly vertical. The caudal vertebrae bear delicate neural and haemal spines. Expanded parapophyses that gradually increase in size posteriorly are present in the six posterior abdominal vertebrae; the morphology of the parapophyses appears to be rather heterogeneous, and most of them are distally pointed. Ribs are preserved only as small fragments.

A poorly preserved caudal skeleton can be observed in NMP Pv 10053a + b (Fig. 4B, C). It has fragments of the fused first preural and ural vertebrae, an indeterminate number of hypurals (?three), a parhypural and two epurals. Of the caudal fin only seven incomplete rays can be observed in the specimen from Loučka.

The dorsal-fin origin seems to be located just behind the head and consists of at least 73 rays. The dorsal-fin rays are well developed, and longer than the opposite anal-fin elements. Usually there are two dorsal-fin pterygiophores inserting in each interneural space. The three anterior dorsal-fin pterygiophores insert in the first interneural space. An incomplete rod-like structure can be recognized in the preneural space; it is difficult to determine whether this structure can be interpreted as a supraneural or not. The anal fin inserts just under the first caudal vertebra and contains at least 64 rays. The distributional pattern of anal-fin pterygiophores is similar to that of the opposite dorsal-fin elements.

The pectoral fin has a wide base and contains about 19 rays. The longest pectoral-fin rays extend posteriorly up to the distal tip of the neural spine of the ninth vertebra. A large cleithrum is partially preserved in the holotype as well as a thin and slender postcleithrum with an expanded proximal portion.

The pelvic fin is poorly preserved and probably consists of only two rays. The basipterygia are not recognizable.

The body is covered by small cycloid scales.

Remarks. - The original description provided by Kramberger (1880) reported a number of features that were not confirmed in our analysis, including (1) a series of short and probably conical dentary teeth; (2) four ( $v s$

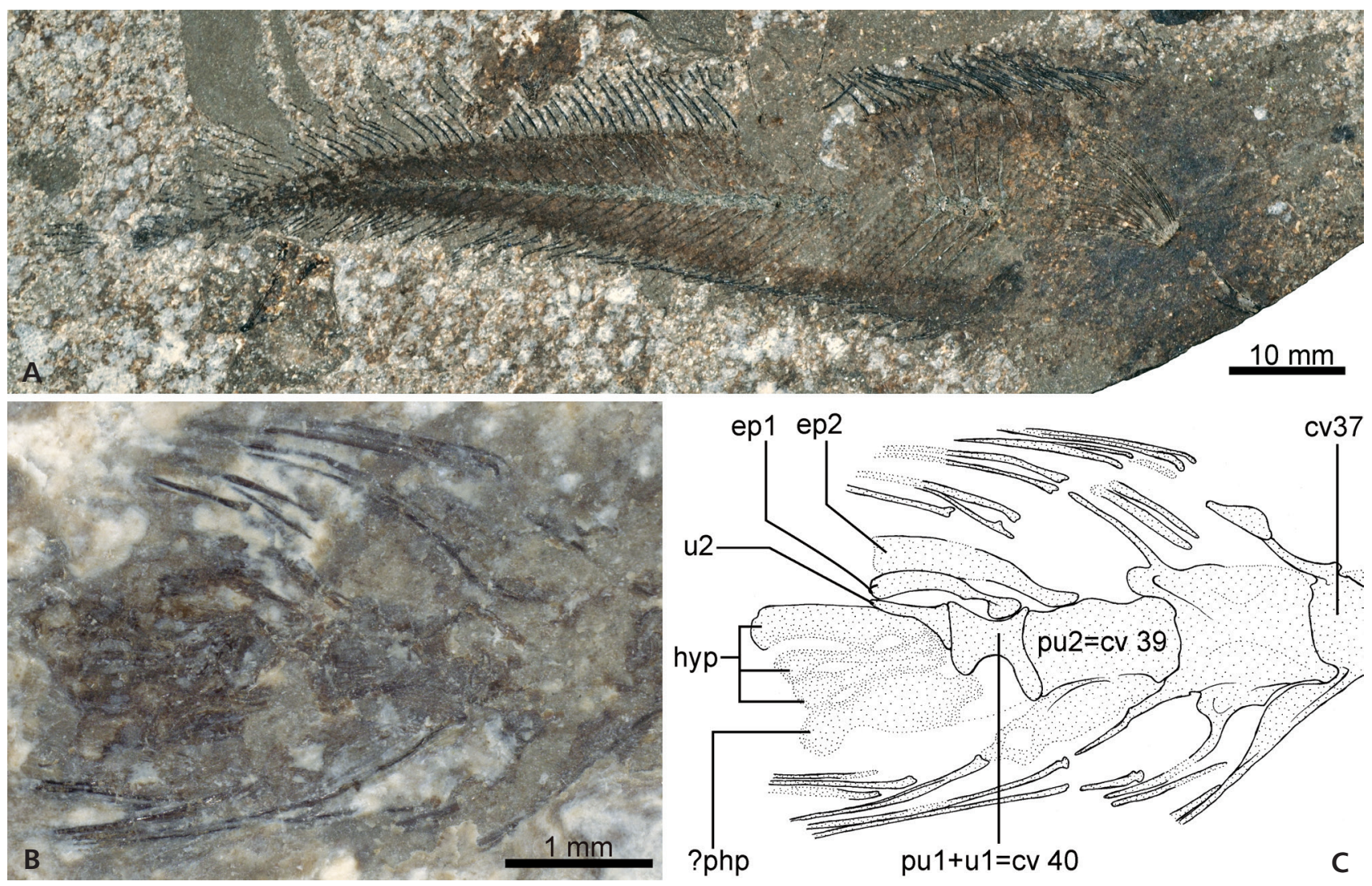

Figure 4. "Brotula" longipinnata Kramberger, 1880. Loučka, Rupelian. A - NMP Pv 10053a, right lateral view; B - detail of the partially preserved caudal skeleton; $\mathrm{C}$ - tentative reconstruction of the caudal skeleton figured in " $\mathrm{B}$ ". 

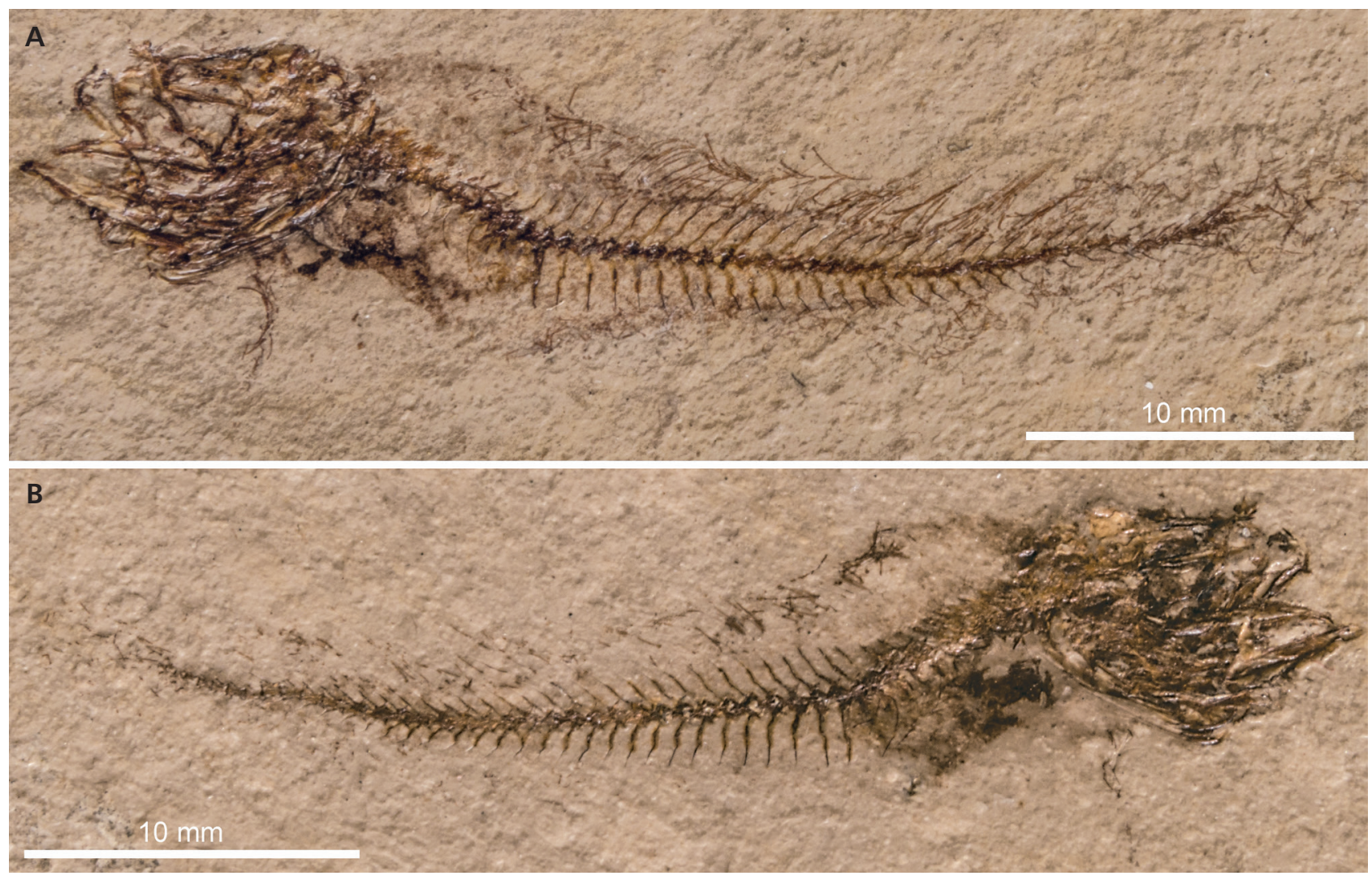

Figure 5. Propteridium profondae Ciobanu, 1970. Mouchnice, Rupelian. A - MZM Ge32143, left lateral view; B - MZM Ge32144, right lateral view.

eight) branchiostegal rays, although eight were figured in Kramberger (1880, pl. 8, fig. 6), suggesting that Kramberger (1880) believed that these derived from both sides; (3) more than 38 (vs 40-41) caudal vertebrae; (4) more than 80 ( $v s$ at least 73 ) dorsal and approximately 40 (vs 64) anal-fins rays; (5) pectoral fin containing 12 (vs 19) rays; (6) pelvic-fin rays not preserved ( $v s$ at least two rays preserved).

The familial assignment of this species is rather problematic due to the lack of diagnostic morphological features. In any case, the presence of body scales, the opercular spine, and the number of vertebrae allow to exclude any attribution to the families Carapidae and Aphyonidae, thereby implying that this species should be placed within the families Ohidiidae or Bythitidae (see e.g. Nelson et al. 2016). The vertebral number $(12+40-41)$ suggests similarity with several genera from both of these families (see Carnevale \& Johnson 2015), such as the ophidiids Brotula, Epetriodus, Neobythites, Pycnocraspedum, and Xyelacyba, and the bythitids Beaglichthys, Grammonus, Lucifuga, Saccogaster, and Tuamotuichthys. However, taking into account also the number of both dorsal- and anal-fin rays (see Carnevale \& Johnson 2015), the meristic complement of "Brotula" longipinnata fits well with those of the bythitids Grammonus, Lucifuga, and Tuamotuichthys (see Nielsen et al.
1999), from which it clearly differs by having a slender and tapering body. In any case, despite these similarities and the clear meristic differences with the genus Brotula, it is not possible to conclusively determine the taxonomic position of this Oligocene species for which additional comparative information would be necessary. Therefore, until additional and more complete material will be available for study, we prefer to cautiously maintain the original taxonomic assignment proposed by Kramberger (1880) in order to avoid additional taxonomic disorder.

Occurrence. - Oligocene, Rupelian, NP23 (Gregorová 1997); Nikolčice (Ždánice Unit; type locality), Loučka (Silesian Unit).

Family Bythitidae Gill, 1861

\section{Genus Propteridium Arambourg, 1967}

\section{Propteridium profondae Ciobanu, 1970}

Figures 5-7

1970 Propteridium profondae n. sp.; Ciobanu, p. 79, pl. 3, fig. 2.

1977 Propteridium profondae nov. sp. [sic!]. - Ciobanu, p. 115 , pl. 38 , fig. 1 . 
cf. 2013 Propteridium Arambourg. - Gregorová, p. 108, unnumbered figure.

Material. - MZM Ge32143 + Ge32144, partially preserved articulated skeleton, in part and counterpart, $37.6 \mathrm{~mm}$ SL, Mouchnice (Figs 5, 6).

Description. - The specimen is moderately wellpreserved, with partially preserved fins. The head is more or less triangular in shape; its length is contained about four times in SL. The cranial bones are difficult to recognize due to inadequate preservation. The ethmoid region is thick and expanded. The vomer is edentulous. The orbit is rather large; its diameter equals the snout length. The frontals are expanded posteriorly, becoming narrow in the orbital region. The mouth gape is slightly oblique and extends posteriorly at the level of the midlength of the orbit. The premaxilla is poorly preserved and bears a single row of tiny and well-spaced teeth. The maxilla is distally expanded and spatulate. The lower jaw protrudes anteriorly beyond the anterior margin of the upper jaw. The lower jaw joint is located at the level of the midlenght of the orbit. The dentary is relatively low. The dentary teeth seem to be similar to those of the upper jaw. There are eight branchiostegal rays.

The vertebral column consists of approximately 47 (12 abdominal plus 35 caudal) vertebrae. The vertebral centra are rectangular, longer than high, becoming smaller and more elongate posteriorly. The five posterior abdominal vertebrae bear large and approximately triangular parapophyses with distally pointed tips (Fig. 6A). Pointed dorsal prezygapophyses are well-developed throughout the vertebral column, whereas ventral prezygapophyses solely characterize the caudal centra (Fig. 6B, C). There are about seven pairs of ribs, of which the posterior rib is associated with the penultimate abdominal vertebra (Fig. 6A). Fragments of intermuscular bones are also preserved; however, their original number and relative position is difficult to interpret.

The median fins and their internal supports are only partially preserved. The caudal fin and its skeletal support are not preserved. The preserved portion of the dorsal fin originates above the seventh or eighth abdominal vertebra, although it seems to be slightly displaced from its original position. About 50 dorsal-fin rays can be recognized, although their original number was certainly higher. The size and limits of the anal fin can be recognized, but due to inadequate preservation it is not possible to interpret the actual number of anal-fin rays and the morphology and configuration of the anal-fin pterygiophores. The dorsal-fin rays appear to be longer than their opposite anal-fin rays.

The pectoral fin contains about 17 elongated rays that extend posteriorly beyond the tenth abdominal vertebra. The structure of the pectoral girdle is unclear.

The pelvic fins are thoracic and contain two filamentous rays. The basipterygia are not recognizable.

Thin and small cycloid scales are preserved in caudal region of the body (at the level of the vertebrae $20^{\text {th }}$ to $23^{\text {th }}$ ).

Remarks. - Despite its incompleteness, the specimens MZM Ge32143 + Ge32144 have a number of features that allow defining its taxonomic affinities. In particular, its overall physiognomy, body proportions (Tab. 1) and structure of the vertebral column are fully consistent with those of the coeval material from Piatra Neamt (Pietricica), Romania referred by Ciobanu (1970, 1977) to Propteridium profondae (Fig. 7). In particular, the specimen described herein shares with the holotype (and until now only known specimen, MSNPN 150) of Propteridium profondae a similar number of vertebrae and pectoral-fin rays, identical morphology and distribution of parapophyses and prezygapophyses, and the overall morphology of the recognizable cranial bones.

Ciobanu $(1970,1977)$ did not provide any justification for the generic attribution of the Romanian specimen to Propteridium. The genus Propteridium was created by Arambourg (1967) based on well-preserved material from the upper Eocene Pabdeh Formation exposed in the vicinity of Ilam, Iran. These fossils were originally considered of Oligocene age and subsequently referred to the Eocene based on the microfossil content of their sedimentary matrix (Afsari et al. 2014). According to Cohen \&

Table 1. Measurements (as percentage of SL) for Propteridium profondae Ciobanu, 1970.

\begin{tabular}{lcc}
\hline & MZM Ge32143 (SL 37.6 mm) & Holotype MSNPN 151 (SL 33 mm) \\
\hline head length & 24.5 & 27.0 \\
head depth & 18.6 & 19.7 \\
preorbital length & 6.6 & 6.7 \\
horizontal diameter of the orbit & 6.4 & 7.0 \\
body depth at the start of dorsal fin & $c a$ 22.1 43.4 & 16.7 \\
preanal length & $c a 58.5$ & 46.7 \\
length of base of the anal fin & 57.0 \\
\hline
\end{tabular}


Table 2. Synopsis of selected meristic features of the genus Propteridium. Includes new data and data from Arambourg (1967).

\begin{tabular}{|c|c|c|c|}
\hline Taxa & $\begin{array}{c}\text { Propteridium douvillei } \\
\text { (Priem, 1908) }\end{array}$ & $\begin{array}{l}\text { Propteridium profondae } \\
\text { Ciobanu, } 1970\end{array}$ & $\begin{array}{l}\text { Propteridium profondae } \\
\text { Ciobanu, } 1970\end{array}$ \\
\hline Age & late Eocene (see Afsari et al. 2014) & early Oligocene & early Oligocene \\
\hline Distribution & Iran (Ilam) & Romania (Piatra Neamţ) & Czech Republic (Mouchnice) \\
\hline $\begin{array}{l}\text { number of } \\
\text { vertebrae }\end{array}$ & $12+37-38$ & $12+35$ & $12+35$ \\
\hline dorsal fin & 80 & slightly more than 80 & ca 50 preserved \\
\hline anal fin & $63-64$ & ca 70 & $?$ \\
\hline pectoral fin & 20 & 17 & 17 \\
\hline pelvic fin & 2 & 2 & 2 \\
\hline caudal fin & 10 & ? & $?$ \\
\hline parapophyses & five posterior abdominal vertebrae & five posterior abdominal vertebrae & five posterior abdominal vertebrae \\
\hline ribs & $?$ & 7 pairs & 7 pairs \\
\hline $\begin{array}{l}\text { premaxillary and } \\
\text { dentary teeth }\end{array}$ & large, needle like & small, needle like & small, needle like \\
\hline scales & $?$ & cycloid & cycloid \\
\hline $\begin{array}{l}\text { branchiostegal } \\
\text { rays }\end{array}$ & 8 & 8 & 8 \\
\hline
\end{tabular}
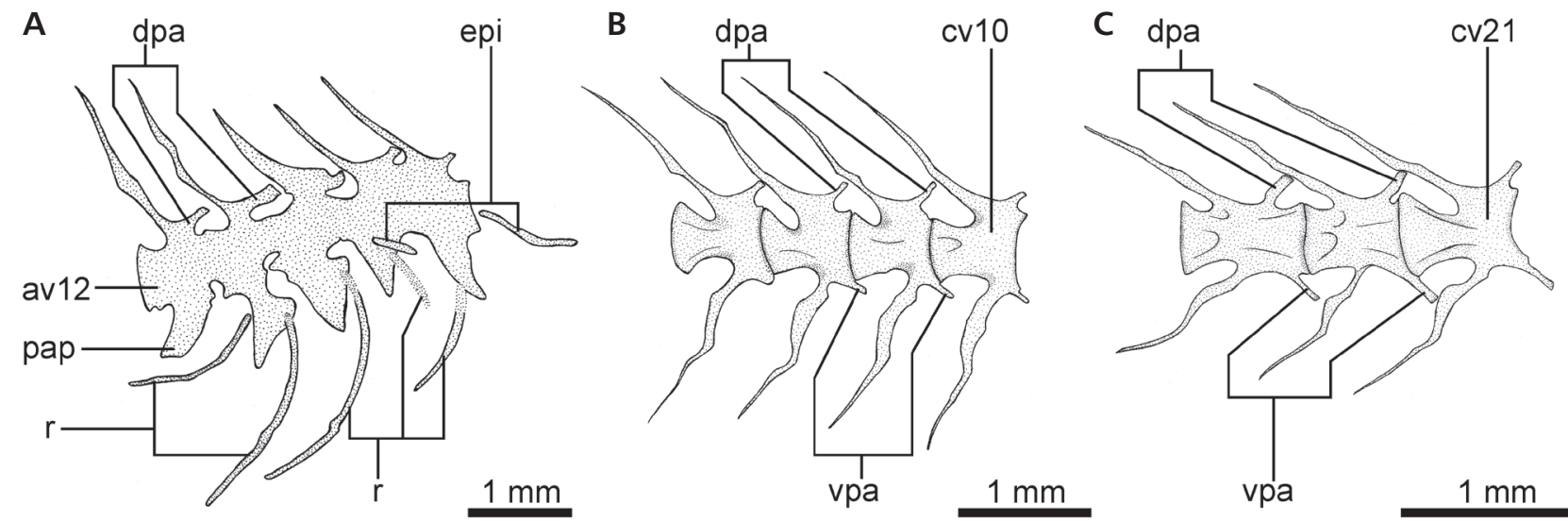

Figure 6. Propteridium profondae Ciobanu, 1970. Mouchnice, Rupelian. Interpretative reconstructions of selected sections of the vertebral column of MZM Ge32144, right lateral views. A $-8^{\text {th }}$ to $12^{\text {th }}$ abdominal vertebrae; $B-10^{\text {th }}$ to $13^{\text {th }}$ caudal vertebrae; $\mathrm{C}-21^{\text {st }}$ to $23^{\text {rd }}$ vertebrae.

Nielsen (1978), Propteridium should be regarded as a member of the family Bythitidae in some ways related to Cataetyx. Based on the description by Arambourg (1967) as well as on the concise account provided by Cohen \& Nielsen (1978), it is difficult to identify one or more features that can support the placement of the Romanian (and Moravian) species within the genus Propteridium. However, a new analysis of the holotype from Pietricica revealed a certain degree of similarity between the Eocene Iranian and the Oligocene Romanian and Moravian species that exhibit similar numbers of vertebrae, medianfin rays, pelvic-fin rays, and branchiostegal rays (Tab. 2).

Occurrence. - Oligocene, Rupelian, NP23 (Gregorová 1997); Mouchnice (Ždánice Unit).
Subfamily Brosmophycinae Gill, 1862

\section{Genus Kalabisia gen. nov.}

Type species. - Kalabisia krumvirensis sp. nov.

Etymology. - In honor of Vladimír Kalabis (September 10, 1910 to January 1, 1985) for his contribution to palaeoichthyology of the Moravian region.

Diagnosis. - A brosmophycine ophidiiform with 41 (16 abdominal plus 25 caudal) vertebrae; large orbit (approximately $20 \%$ of head length); neural spine of the first abdominal vertebra elongate, reaching the size of the succeeding ones; parapophyses absent except for a short 
one emerging from the lateroventral side of the posterior abdominal centrum; dorsal-fin origin located above the third abdominal vertebra, approximately at one third of SL.

\section{Kalabisia krumvirensis sp. nov.}

Figures 8-11

Holotype. - NMP Pv 11198, partially complete articulated skeleton lacking most of the median and paired fins, $32.3 \mathrm{~mm}$ SL.

Type horizon and locality. - Oligocene-early Miocene, Egerian, NN1 (Gregorová 1997); Krumvíř (Ždánice Unit).
Material. - The holotype is only known specimen of the species.

Etymology. - The species name is derived from the type locality Krumviŕr.

Diagnosis. - As for the genus.

Description. - The body is elongate, and laterally compressed, with the head occupying about one third of SL. The head is poorly preserved and characterized by a moderate-sized eye (slightly smaller than the snout length; Tab. 3). Of the neurocranium, only the ethmoids,

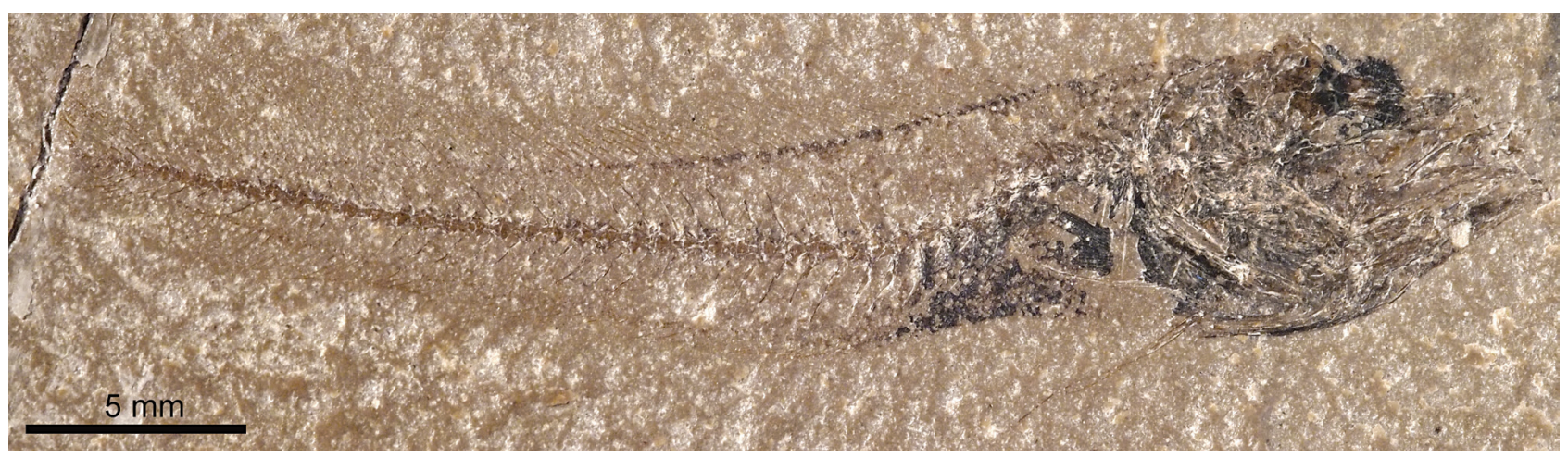

Figure 7. Propteridium profondae Ciobanu, 1970. Piatra Neamţ (Pietricica), Romania, Rupelian. MSNPN 150, holotype, right lateral view.
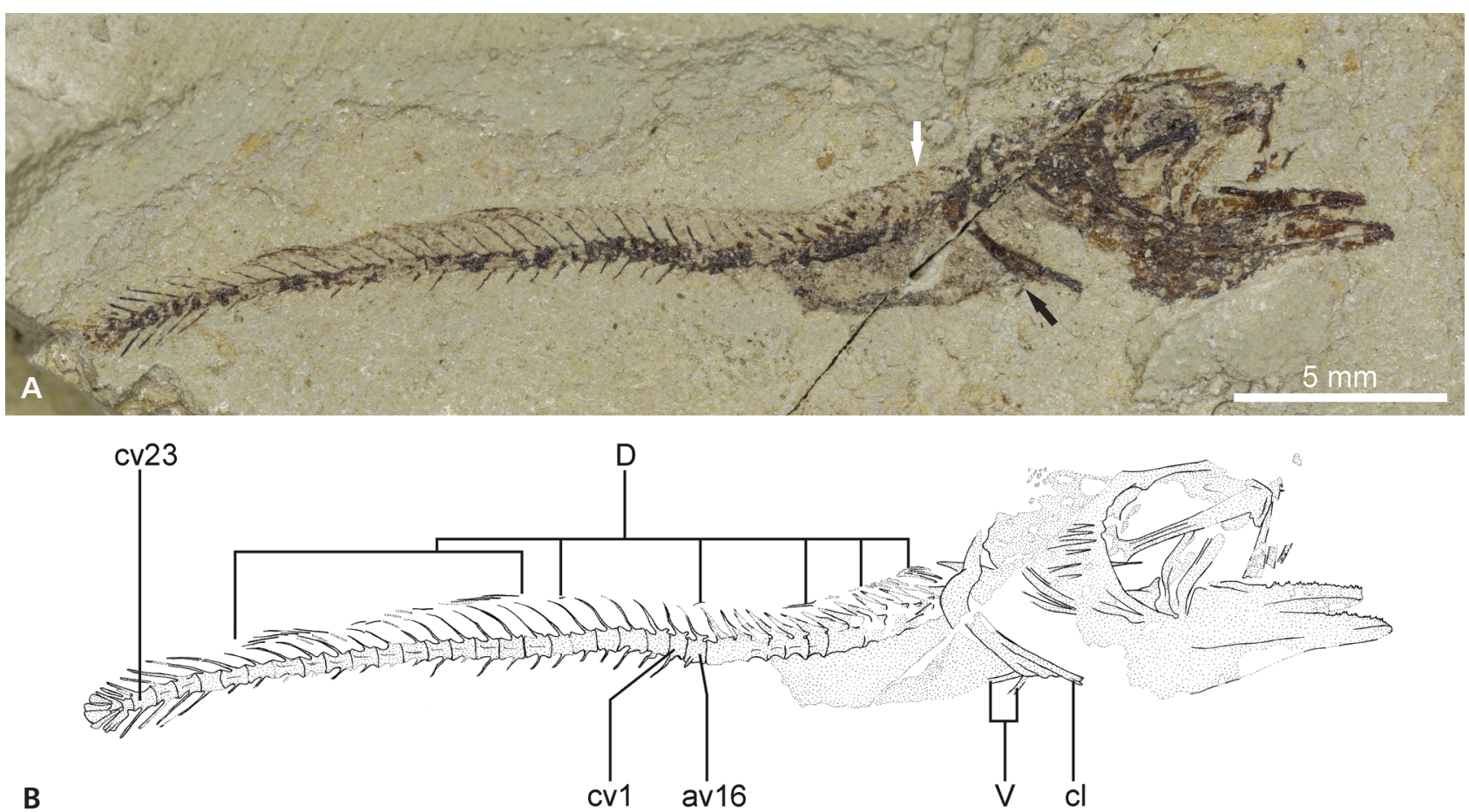

Figure 8. Kalabisia krumvirensis gen. \& sp. nov. Krumvír, Egerian. A - NMP Pv 11198, holotype, right lateral view; B - interpretative reconstruction of "A". The white arrow indicates the dorsal-fin insertion; the black arrow indicates position of the pelvic fins. 

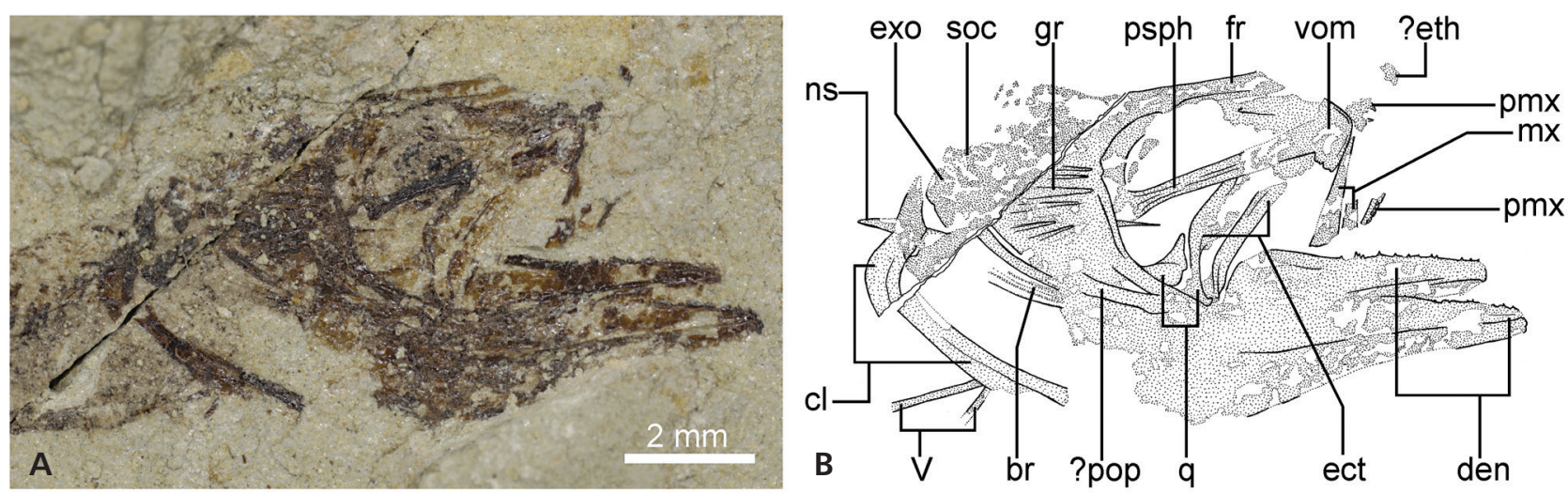

Figure 9. Kalabisia krumvirensis gen. \& sp. nov. Krumvír, Egerian. NMP Pv 11198, holotype. A - head, right lateral view; B - interpretative reconstruction of "A".

Table 3. Morphometric features (as percentage of SL) of Kalabisia krumvirensis gen. \& sp. nov. and extant species of the genera Brosmodorsalis and Bidenichthys. Includes new data and data from Barnard (1934), Paulin \& Roberts (1989) and Paulin (1995).

\begin{tabular}{|c|c|c|c|c|c|}
\hline & $\begin{array}{l}\text { Kalabisia krumvirensis } \\
\text { gen. \& sp. nov. }\end{array}$ & $\begin{array}{c}\text { Bidenichthys } \\
\text { capensis }\end{array}$ & $\begin{array}{l}\text { Bidenichthys } \\
\text { consobrinus }\end{array}$ & $\begin{array}{c}\text { Bidenichthys } \\
\text { beeblebroxi }\end{array}$ & $\begin{array}{c}\text { Brosmodorsalis } \\
\text { persicinus }\end{array}$ \\
\hline head length & 28.2 & $26.7-27.3$ & $30.3-33$ & $26-32$ & $26-31.4$ \\
\hline preorbital length & 7.7 & $5.8-8.4$ & $7.2-8.4$ & $5.3-7.2$ & $?$ \\
\hline $\begin{array}{l}\text { horizontal diameter } \\
\text { of the orbit }\end{array}$ & 5.0 & $3.9-4.2$ & $4.3-5.2$ & $3.5-4.9$ & $3.3-5$ \\
\hline predorsal length & 31.6 & ? & $20.9-37.7$ & $29.8-38.8$ & $16.9-22.9$ \\
\hline
\end{tabular}

frontal, supraoccipital and exoccipital can be observed, although without recognizable details. The parasphenoid is straight and relatively strong, located in the lower third of the orbit; it articulates anteriorly with the vomer. The ectopterygoid seems to be gently curved and articulates posteriorly with a small quadrate. Both the premaxilla and maxilla are only fragmentarily preserved; small and recurved premaxillary teeth are recognizable. The dentary is rather large and massive; it protrudes beyond the anterior margin of the upper jaw and bears slightly recurved teeth. The lower jaw joint is located at the level of the posterior half of the orbit. The opercular region is badly damaged and only the preopercle seems to be recognizable. Elongate and slightly curved branchiostegal rays are partially preserved, but their original number is not clear. Several gill rakers are recognizable in the opercular region, but their morphology and distribution are not clear (Fig. 9).

The vertebral column consists of 41 (16 abdominal and 25 caudal) vertebrae. Well-developed dorsal prezygapophyses are present from the posterior abdominal vertebra posteriorly. A small paraphophysis is present on the last abdominal vertebra (Fig. 10).

The caudal skeleton is partially preserved (Fig. 11) and suggests the presence of two epurals, probably three unfused hypurals, parhypural, and haemal spine of second preural vertebra (that represents the $24^{\text {th }}$ caudal vertebra) widened anteroposteriorly. On the other hand, due to the state of preservation this interpretation is only tentative. There is no evidence of the caudal fin. The dorsal fin is poorly preserved, with only a few fragments of pterygiophores and fin rays recognizable; the first dorsal-fin pterygiophore can be recognized, providing evidence that the dorsal-fin origin is located approximately at one third of SL, just above the third abdominal vertebra. The anal fin is not preserved.

The pectoral fin is not preserved. The cleithrum is crescent-shaped, massive and slightly displaced from its original position. The pelvic fins are represented by

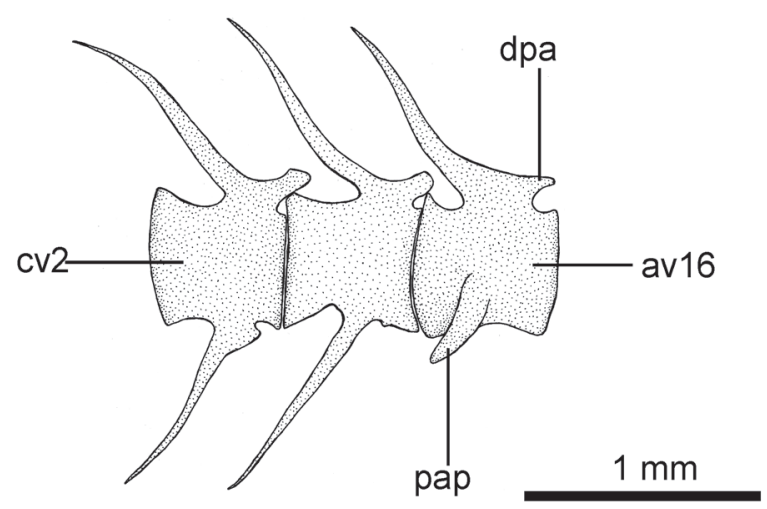

Figure 10. Kalabisia krumvirensis gen. \& sp. nov. Krumviŕ, Egerian. Interpretative reconstruction of the last abdominal and first two caudal vertebrae of the holotype NMP Pv 11198. 

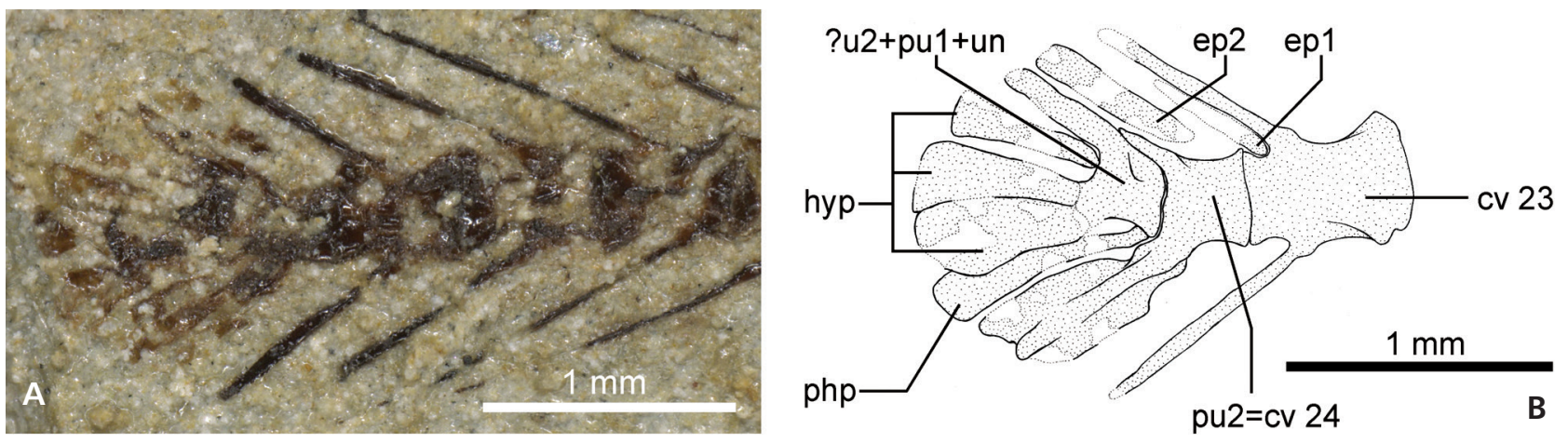

Figure 11. Kalabisia krumvirensis gen. \& sp. nov. Krumvír, Egerian. A - caudal skeleton of the holotype NMP Pv 11198; B - interpretative reconstruction of "A".

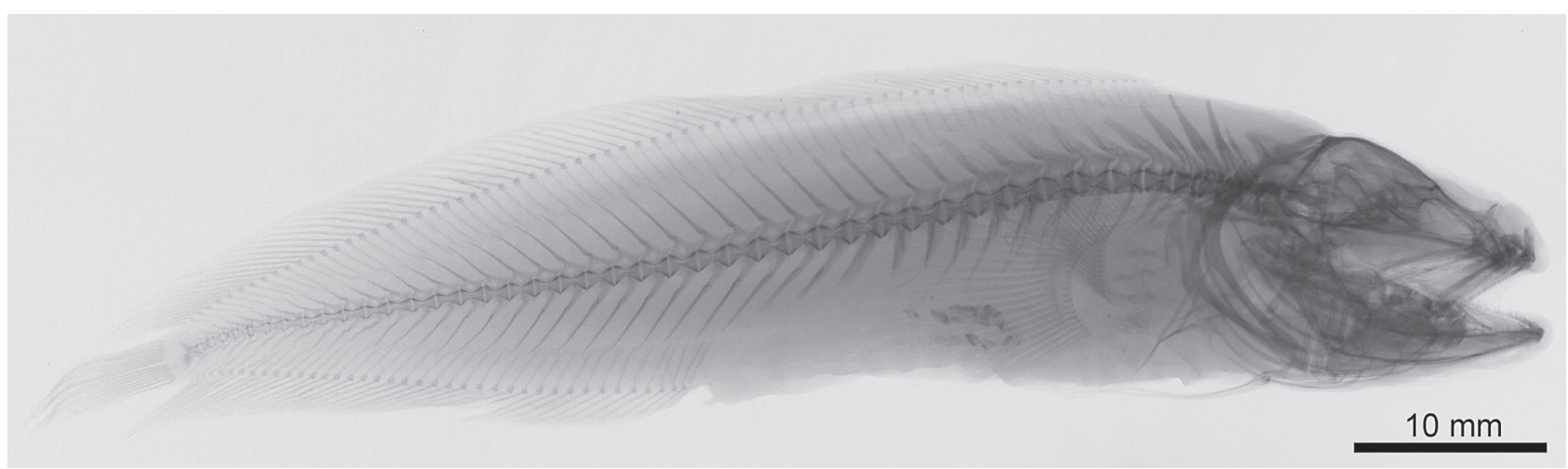

Figure 12. Bidenichthys capensis Barnard, 1934. Inverted radiograph of the specimen USNM 188816. Courtesy of Sandra J. Raredon, Smithsonian Institution, Washington.

fragments of a single ray for each of the fins. The basipterygium is not preserved.

Discussion. - Despite its incompleteness, the specimen provides a set of features that support its recognition as a new ophidiiform genus. The possession of a single ray in the pelvic fin and the reduced number of vertebrae justify its assignment to the brosmophycine bythitids (see Cohen \& Nielsen 1978, Nielsen et al. 1999, Carnevale \& Johnson 2015). Within the brosmophycines, Kalabisia gen. nov. exhibits a vertebral formula that is consistent with that of the genera Bidenichthys and Brosmodorsalis (Carnevale \& Johnson 2015). However, it clearly differs from Brosmodorsalis by having the dorsal-fin insertion placed above the third abdominal vertebra, well posterior to the opercular region, neural spines well-developed on the abdominal vertebrae, and parapophyses absent on most abdominal vertebrae; as reported by Paulin \& Roberts (1989), Brosmodorsalis is characterized by an occipital insertion of the dorsal fin, definitely anterior to the posterior margin of the opercle, as well as by neural spines of abdominal vertebrae depressed, and parapophyses present in the posterior ten abdominal vertebrae (Paulin \& Roberts 1989). As far as the genus Bidenichthys is concerned, it clearly differs from Kalabisia gen. nov. by having a first neural spine shorter than the succeeding spines, and well developed parapophyses on the posterior ten abdominal vertebrae (compare Figures 8 and 12; Paulin 1995; Nielsen et al. 1999).

\section{Discussion}

\section{The Oligo-Miocene Paratethyan record of ophidiiform fishes}

Beside Brotula longipinnata and Propteridium profondae that were originally found in Moravia and Romania (see, respectively Kramberger 1880 and Ciobanu 1970, 1977), there are few additional records of ophidiiform fishes from the Oligocene and lower Miocene deposits of the Paratethys.

Paucă (1931) described Ophidium (?) longipinnatus from the Oligocene of Piatra Neamţ, Romania, based on a single articulated skeleton lacking the head and the abdominal part of the body axis. The specimen has 28 vertebrae representing only part of the caudal portion of the body. There is no evidence of diagnostic ophidiiform 
characters in this fossil and the apparent separation of the caudal fin from the dorsal and anal fins may suggest that it should not be regarded as an ophidiiform. Unfortunately, we were unable to locate the specimen for a comparative analysis.

Paucă (1933) transferred the species Gadus carpathicus, established by Böhm (1930), from the Ukrainian Carpathians to the genus Ophidium and considered the new combination, Ophidium (?) carpathicus, as senior synonym of Ophidium (?) longipinnatus. The species Gadus carpathicus was created by Böhm (1930; p. 71 and tab. 2) without any description, figure or reference of existing or forthcoming publication. Paucă (1933) provided a short description of two specimens (measuring 140 and $236 \mathrm{~mm}$ of total lenght, respectively) from the Böhm's collection in Lvov, Ukraine, and concluded that these should be regarded as ophidiiforms rather than gadiforms. However, based on his description (Paucă 1933), it is not possible to recognize any diagnostic feature that can support an attribution to the Ophidiiformes. Moreover, in this case it was also not possible to locate these specimens to determine their taxonomic affinities.

The Oligocene species Protobrotula sobijevi from the Maikopian deposits of North Caucasus was formerly described by Daniltshenko (1953) as a Moridae and subsequently regarded as an ophidiiform (Daniltshenko 1960). Prokofiev $(2001,2003)$ provided a detailed redescription of the available material and of evidence of its possible relationships to the brosmophycines based on the presence of a well-developed caudal fin clearly separated from both the dorsal and the anal fins, as well as of a comparatively low number of vertebrae.

Świdnicki (1988) referred a single articulated skeleton in part and counterpart from the Oligocene of Poland to Glyptophidium sp. and additional specimens were mentioned by Kotlarczyk et al. (2006). Based on the accurate and detailed description by Świdnicki (1988), it is possible to confirm its taxonomic interpretation. The taxonomic status of additional ophidiiform material listed in Kotlarczyk et al. (2006) has not been verified due to the problematic access to material.

An Oligocene-Miocene (Egerian) fossil ophidiiform from Krumviŕ was reported by Brzobohatý et al. (1975) and referred to as Ophidion sp. The description of the single available fossil is extremely brief and without figures, making it difficult to evaluate its taxonomic status. Finally, in an unpublished report, Kalabis (1966) described an incomplete caudal portion of the body from Krumvirir as a flatfish, although the associated photograph clearly reveals its ophidiiform affinities. The location of these specimens is unknown but the size and body proportions are different from those observed in the new genus and species described herein, suggesting a separate taxonomic placement.

\section{Conclusions}

The fossil specimens from Moravia reported herein provide evidence of the existence of at least two early Oligocene species-level taxa, one of uncertain taxonomic position and another tentatively referred to the Bythitidae, as well as of a new brosmophycine genus and species of Oligocene-early Miocene (Egerian) age.

According to the available data, "Brotula" longipinnata appears to be restricted to the lower Oligocene deposits of Moravia, while Propteridium profondae seems to be known from the approximately coeval deposits of Pietricica, Romania. To date, three ophidiid otolithbased taxa, Glyptophidium major, Hoplobrotula sp., and "g. Ophidiidarium" rzehaki, and a single bythitid otolithbased species, " $g$. Bythitidarum" marchicus, have been reported from the lower Oligocene deposits of Moravia (Brzobohatý \& Krhovský 1998) and two ophidiid taxa, Bythitinae indet. and Neobythitinae indet., have been recorded from the Egerian deposits of northeastern Hungary (Nolf \& Brzobohatý 1994). However, until new skeletal material with otoliths in situ becomes available, it will not be possible to correlate these two records.

In conclusion, the analysis of the Oligocene to early Miocene skeletal record of the ophidiiform fishes indicates that at least five genus-level taxa were present in the Paratethys realm, including "Brotula", Glyptophidium, Propteridium, Protobrotula and Kalabisia gen. nov. The members of the family Bythitidae occur worldwide in the Atlantic, Indian and Pacific oceans and, contrary to the ophidiids, some of them extend their range into shallow waters (Nelson et al. 2016). However, the fish assemblages associated with the ophidiiforms described herein point to mesopelagic to bathypelagic palaeobiotopes (e.g. Gregorová 1997, 2011).

\section{Acknowledgement}

We are grateful to Irene Zorn (Geologische Bundesanstalt, Vienna), Růžena Gregorová (Moravian Museum, Brno), Boris Ekrt (National Museum, Prague), and Ionuţ Grădianu (Natural Sciences Museum, Piatra Neamţ) for access to collections under their care. Ionuţ Grădianu (Piatra Neamţ) is acknowledged for providing a photograph of the specimen MSNPN 150. We are grateful for the opportunity to use Keyence microscope at the National Museum in Prague. Many thanks go to Alexandre F. Bannikov (Borisyak Paleontological Institute, Russian Academy of Sciences, Moscow) and James C. Tyler (National Museum of Natural History, Smithsonian Institution, Washington) for constructive advice on improving the manuscript. The research of T.P. was supported by a grant from the Czech Science Foundation (16-21523S) and institutional support by the Czech Academy of the Sciences, Institute of Geology (RVO67985831). The research of G.C. was supported by grants (ex-60\% 2016 and 2017) from the Università degli Studi di Torino. 


\section{References}

Afsari, S., Yazdi, M., Bahrami, A. \& Carnevale, G. 2014. A new deep-sea hatchetfish (Teleostei: Stomiiformes: Sternoptychidae) from the Eocene of Ilam, Zagros Basin, Iran. Bollettino della Societa Paleontologica Italiana 53, $27-37$.

Arambourg, C. 1967. Les Poissons oligocénes de l'Iran. Notes et mémoires sur le Moyen-Orient 8, 9-247.

BARNARD, K.H. 1934. New records and descriptions of two new species of South African marine fishes. Annals and magazine of natural history 10, 228-234.

DOI 10.1080/00222933408654806

BERG, L.S. 1937. A classification of fish-like vertebrates. Izvestiya Akademii Nauk SSSR 1937, 1277-1280.

Вӧнм, В. 1930. Stratygrafja trzeciorzędu karpackiego na podstawie fauny rybiej. Pamiêtnik Pierwszego Zjazdu Geologiczno-Naftowego we Lwowie, 14-15 grudnia 1929, Warszawa-Borysław-Lwów, 67-79.

Brzobohatý, R. \& Krhovský, J. 1998. A synopsis of the Teleost taxa (otoliths) from the Pouzdrrany Formation (West Carpathians, Pouzdřany Unit, Early Oligocene). Zemní plyn a nafta 43, 279-289.

Brzobohatý, R., Kalabis, V. \& Schultz, O. 1975. Die Fischfauna des Egerien, 457-477. In Baldi, T. \& Seneš, J. (eds) Egerien. Die Egerer, Pouzdraner, Puchkirchener Schichtengruppe und die Bretkaer Formation. Chronostratigraphie und Neostratotypen. Miozän der zentralen Paratethys 5.

Carnevale, G. \& Godfrey, S.J. 2018. Miocene bony fishes of the Calvert, Choptank, St. Marys, and Eastover Formations, Chesapeake Group, Maryland and Virginia. Smithsonian Contributions to Paleobiology 100, 161-212.

Carnevale, G. \& Johnson, G.D. 2015. A Cretaceous Cusk-Eel (Teleostei, Ophidiiformes) from Italy and the Mesozoic diversification of Percomorphf. Copeia 103, 771-791. DOI 10.1643/CI-15-236

Carnevale, G., Bannikov, A.F., Marramà, G., Tyler, J.C. \& Zorzin, R. 2014. The Pesciara Monte Postale FossilLagerstätte: 2. Fishes and other vertebrates, 37-63. In Papazzoni, C.A., Giusberti, L., Carnevale, G., Roghi, G., BAssi, D. \& Zorzin, R. (eds) The Bolca Fossil-lagerstätte: A window into the Eocene World. Rendiconti della Società Paleontologica Italiana 4.

Chen, W.J., Santini, F., Carnevale, G., Chen, J.N., Liu, S.H., Lavoué, S. \& Mayden, R.L. 2014. New insights on early evolution of spiny-rayed fishes (Teleostei: Acanthomorpha). Frontiers in Marine Science 1, 53. DOI 10.3389/fmars.2014.00053

Ciobanu, M. 1970. Date noi asupra peştilor fosili din Oligocenul dela Piatra Neamţ (II). Studii şi Cercetari 1, 67-90.

Ciobanu, M. 1977. Fauna fosilă din Oligocenul de la Piatra Neamţ. 159 pp. Editura Academiei Republicii Socialiste România, Bucureşti.

Cohen, D.M. \& Nielsen, J.G. 1978. Guide to the identification of genera of the fish order Ophidiiformes with a tentative classification of the order. NOAA Technical Report NMFS Circular 417, 1-72.
ČTYŘOKÝ, P. \& STRÁNíK, Z. 1995. Zpráva pracovní skupiny české stratigrafické komise o regionálním dělení Západních Karpat. Bulletin of the Czech Geological Survey 70, 67-72.

Daniltshenko, P.G. 1953. Iskopaemye predki sovremennych Moridae. Voprosy ichtiologii 1, 117-127.

Daniltshenko, P.G. 1960. Kostistiye ryby maikopskich othlozeniy Kavkaza. Trudy Paleontologicheskogo Instituta AN SSSR 78, 1-247.

Daniltshenko, P.G. 1968. Fishes from the Upper Paleocene of Turkmenia, 113-156. In OBRuchev, D.V. (ed.) Ocherki po filogenii i sistematike iskopayemykh ryb i beschelyustnykh. Nauka, Moscow.

GiLl, T.N. 1861. Catalogue of the fishes of the western coast of North America. Proceedings of the Academy of Natural Sciences of Philadelphia 1861, 1-63.

GILL, T.N. 1862. Notice of a collection of the fishes of California, presented to the Smithsonian Institution, by Mr. Samuel Hubbard. Proceedings of the Academy of Natural Sciences of Philadelphia 1862, 274-282.

GregorovÁ, R. 1997. Vývoj společenstev rybí a žraločí fauny v oligocénu vnějších Západních Karpat (Morava) a jejich význam pro paleoekologii, paleobatymetrii a stratigrafii, 29-35. In Hladilová, Š. (ed.) Dynamika vztahů marinního a kontinentálního prostředi. Sbornik príspevkü. Grantový projekt GAČR 205/95/1211, Brno.

GregorovÁ, R. 2011. Fossil fish fauna (Teleostei, Selachii) from the Dynów marlstone (Rupelian, NP 23) of the Menilitic Formation at the locality of Litenčice (Czech Republic). Acta Musei Moraviae, Scientiae Geologicae 96, 3-33.

Gregorová, R. 2013. Tajemné moře v Karpatech. 159 pp. Moravské Zemské Muzeum, Brno.

Howes, G.J. 1992. Notes on the anatomy and classification of ophidiiform fishes with particular reference to the abyssal genus Acanthonus Günther, 1878. Bulletin of the British Museum of Natural History (Zoology) 58, 95-131.

KALABIS, V. 1966. Zpráva o rybí fauně v ždánícko-hustopečském souvrství na lokalitě Krumvír. $18 \mathrm{pp}$. Unpublished MS Geofond, Prague.

Kotlarczyk, J., Jerzmańska, A., Świdnicka, E. \& Wiszniowska, T. 2006. A framework of ichthyofaunal ecostratigraphy of the Oligocene-Early Miocene strata of the Polish Outer Carpathian Basin. Annales Societatis Geologorum Poloniae 76, $1-111$.

Kramberger, D. 1880. Die fossilen Fische von Wurzenegg bei Prassberg in Steiermark. Jahrbuch der Kaiserlich Königlichen Geologischen Reichsanstalt 30, 565-572.

Leonardi, A. 1959. L'ittiofauna del "Tripoli" del Miocene superiore di Bessima (Enna). Palaeontographia Italica 54, 115-173.

Markle, D.F. \& Olney, J.E. 1990. Systematics of the pearlfishes (Pisces: Carapidae). Bulletin of Marine Science 47, 269-410.

Nelson, J.S., Grande, T.C. \& Wilson, M.V.H. 2016. Fishes of the World, Fifth Edition. 752 pp. John Wiley \& Sons, inc., Hoboken. DOI 10.1002/9781119174844

Nielsen, J.G., Cohen, D.M., Markle, D.F. \& Robins, C.R. 1999. Ophidiiform fishes of the world (Order Ophidiiformes) An annotated and illustrated catalogue of pearlfishes, cusk-eels, 
brotulas and other ophidiiform fishes known to date. FAO Fisheries Synopsis No. 125(18), 1-178.

Nolf, D. 1980. Etude monographique des otolithes des Ophidiiformes actuels et révision des espèces fossils (Pisces, Teleostei). Mededelingen van de Werkgroep voor Tertiaire en Kwartaire Geologie 17, 71-195.

Nolf, D. 2013. The Diversity of Fish Otoliths, Past and Present. 581 pp. Royal Belgian Institute of Natural Sciences, Brussels.

Nolf, D. \& Brzobohatý, R. 1994. Fish otoliths from the Late Oligocene (Eger and Kiscell Formations) in the Eger area (northeastern Hungary). Bulletin de l'Institut royal des Sciences naturelles de Belgique, Sciences de la Terre 64, 225-252.

PAUCĂ, M. 1931. Neue fische aus dem Oligozän von Piatra Neamţ. Bulletin de l'Académie Roumaine, Section scientifique 14, 29-34.

PaucĂ, M. 1933. De nouveaux Poissons fossiles dans l'Oligocene de Piatra Neamț. Comptes Rendus des séances de l'Institut Géologique de Roumanie 19, 89-97.

Paulin, C.D. 1995. Description of a new genus and two new species of bythitid fishes, and a redescription of Bidenichthys consobrinus (Hutton) from New Zealand. Journal of Natural History 29, 249-258. DOI 10.1080/00222939500770121

Paulin, C.D. \& RoberTs, C.D. 1989 A new genus and species of bythitid fish (Teleostei: Ophidiiformes) from New Zealand. Journal of Natural History 23, 355-361. DOI 10.1080/00222938900770221

Priem, F. 1908. Poissons fossiles de Perse (Mission de Morgan). Annales d'Histoire naturelle, Paléontologie 1, 1-25.

Prokofiev, A.M. 2001. Redescription of Protobrotula sobijevi (Daniltshenko, 1953) (Paracanthopterygii, Ophidiiformes) from the Lower Oligocene of the Caucasus. Journal of Ichthyology 41, 481-485.

Prokofiev, A.M. 2003. Morphology of basicranium of Protobrotula sobijevi (Ophidiiformes) with notes on systematic position of the genus. Journal of Ichthyology 43, 146-150.
Přikryl, T. \& Carnevale, G. 2017. An Oligocene toadfish (Teleostei, Percomorpha) from Moravia, Czech Republic: The earliest skeletal record for the order Batrachoidiformes. Bulletin of Geosciences 92, 123-131.

DOI 10.3140/bull.geosci.1662

Př̀nryl, T., Prokofiev, A.M. \& Krzemiński, W. 2012. Feeding habits of the Oligocene bristlemouth fish Scopeloides glarisianus (Teleostei: Stomiiformes: Gonostomatidae). Geobios 45, 377-386.

DOI 10.1016/j.geobios.2011.10.012

Riva Rossi, C.M., Gosztonyi, A.E. \& Cozzuol, M.A. 2000. A Miocene cusk-eel (Ophidiiformes: Ophidiidae) from Península Valdés, Argentina. Journal of Vertebrate Paleontology 20, 645-650.

DOI 10.1671/0272-4634(2000)020[0645:AMCEOO]2.0.CO;2

Rosen, D.E. 1985. An essay on euteleostean classification. American Museum Novitates 2827, 1-45.

SAto, J. 1962. Miocene fishes from the western area of Shizukuishi Basin, Iwate Prefecture, northeastern Japan. Earth Science (Chikyu Kagaku) 59, 1-29.

Schwarzhans, W. 1981. Vergleichende morphologische Untersuchungen an rezenten und fossilen Otolithen der Ordnung Ophidiiformes. Berliner geowissenschaftliche Abhandlungen A 32, 63-122.

Schwarzhans, W., Beckett, H.T., Schein, J.D. \& Friedman, M. 2018. Computed tomography scanning as a tool for linking the skeletal and otolith-based fossil records of teleost fishes. Palaeontology 61(4), 511-541. DOI 10.1111/pala.12349

ŚwIDNICKI, J. 1988. Najstarszy kopalny przedstawiciel rodzaju Glyptophidium Alcock (Ophidiiformes). Przeglad zoologiczny 32, 401-404.

Wiley, E.O. \& Johnson, G.D. 2010. A teleost classification based on monophyletic groups, 123-182. In Nelson, J.S., Schultze, H.P. \& Wilson, M.V.H. (eds) Origin and Phylogenetic Interrelationships of Teleosts. Verlag Dr. Friedrich Pfeil, München. 